Pesq. Vet. Bras. 37(9):941-948, setembro 2017

DOI: $10.1590 / \mathrm{S} 0100-736 \mathrm{X} 2017000900008$

\title{
Pseudomonas spp.: contamination sources in bulk tanks of dairy farms ${ }^{1}$
}

\author{
Ana M.C. Vidal' ${ }^{2}$, Arlindo Saran Netto ${ }^{3}$, Andreia C.N. Vaz ${ }^{2}$, Eduardo \\ Capodifóglio ${ }^{3}$, Ana C.S. Gonçalves ${ }^{4}$, Gabriel A.M. Rossi ${ }^{4}$, Annanda S. \\ Figueiredo ${ }^{2}$ and Vera L.A. Ruiz ${ }^{2 *}$
}

\begin{abstract}
Vidal A.M.C., Saran Netto A., Vaz A.C.N., Capodifóglio E., Gonçalves A. C.S., Rossi G.A.M., Figueiredo A.S. \& Ruiz V.L.A. 2017. Pseudomonas spp.: contamination sources in bulk tanks of dairy farms. Pesquisa Veterinária Brasileira 37(9):941-948. Departamento de Medicina Veterinária, Faculdade de Zootecnia e Engenharia de Alimentos, Universidade de São Paulo, Avenida Duque de Caxias Norte 225, Pirassununga, SP 13635-900, Brazil. E-mail: letticie@usp.br

This study focused on isolating Pseudomonas spp. during milking process in ten dairy farms with manual and mechanical milking systems during dry and rainy seasons, and evaluating DNA homology and patterns of distribution between isolates, in order to identify main sources of milk contamination by Pseudomonas spp. A total of 167 isolates of Pseudomonas spp. were obtained from water, milkers' hands, cows' teats, teat cups, cooling tanks and raw milk. Bacteria of Pseudomonas spp. genus were isolated from 85 and 82 sampling points in dairy farms with manual and mechanical milking system, respectively. A significant difference $(\mathrm{p}=0.02)$ on Pseudomonas spp. isolation was observed among samples of surface of cows' teats before and after pre-dipping, but no significant difference $(\mathrm{p}>0.05)$ was observed among milking systems or seasons. The possibility of the same Pseudomonas spp. patterns are distributed in different farms and seasons using Amplified Fragment Length Polymorphism (AFLP) technique was demonstrated. Milkers' hands, surface of cows' teats, teat cups and cooling tanks were associated with raw milk contamination with Pseudomonas spp. on farms with manual and mechanical milking system, showing that regardless of the type of milking system and season, proper hygiene procedures of equipment, utensils and workers' hands are essential to avoid contamination of the milk and, therefore, improve milk quality.
\end{abstract}

INDEX TERMS: Pseudomonas spp., ecology, contamination, bulk tanks, dairy farms, Amplified Fragment Length Polymorphism technique, AFLP, milk, food microbiology, psychrotolerant.

RESUMO.- [Pseudomonas spp.: fontes de contaminação em tanques de expansão em fazendas leiteiras.] Este estudo se propôs a isolar Pseudomonas spp. durante o processo de ordenha em dez fazendas com sistemas manuais

\footnotetext{
${ }^{1}$ Received on November 4, 2016.

Accepted for publication on March 23, 2017.

${ }^{2}$ Departamento de Medicina Veterinária, Faculdade de Zootecnia e Engenharia de Alimentos (FZEA), Universidade de São Paulo (USP), Av. Duque de Caxias Norte 225, Pirassununga, SP 13635-900, Brazil. *Corresponding author: letticie@usp.br

${ }^{3}$ Departamento de Zootecnia, (FZEA-USP), Av. Duque de Caxias Norte 225, Pirassununga, SP 13635-900, Brasil.

${ }^{4}$ Departamento de Medicina Veterinária Preventiva e Reprodução Animal, Faculdade de Ciências Agrárias e Veterinárias, Universidade Estadual Paulista (Unesp), Rodovia Paulo Donato Castellane s/n, Jaboticabal, SP 14884-900, Brasil.
}

e mecanizados, durante as estações seca e chuvosa, além de avaliar a homologia do DNA e seus padrões de distribuição entre os isolados, a fim de se determinar as principais fontes de contaminação do leite. Cento e sessenta e sete isolados de Pseudomonas spp. foram obtidos a partir de amostras de água, mãos de ordenhadores, tetos, teteiras, tanques de resfriamento e leite cru armazenado, sendo 85 e 82 pontos de amostragem em fazendas com sistemas de ordenha manual e mecânico, respectivamente. Diferença estatisticamente significativa foi encontrada entre os isolados observados entre a superfície dos tetos antes e após o pré-dipping $(\mathrm{p}=0,02)$, mas nenhuma diferença foi encontrada entre sistemas de ordenha ou estações $(p>0,05)$. A possibilidade do mesmo padrão de Pseudomonas spp. estar distribuído em diferentes fazendas ou estações foi avaliada 
pela técnica de Polimorfismo do Tamanho de Fragmento Amplificado (AFLP). As mãos de ordenhadores, superfície dos tetos das vacas, teteiras e tanques de resfriamento foram associados com a contaminação do leite cru, demonstrando que independente do tipo de ordenha e estação, a higiene adequada de equipamentos, utensílios e mãos dos ordenhadores é essencial para evitar contaminação do leite, e consequentemente aumentar sua qualidade.

TERMOS DE INDEXAÇÃO: Pseudomonas spp., ecologia, contaminação, tanques de expansão, Polimorfismo do Tamanho de Fragmento Amplificado, fazendas leiteiras, leite, microbiologia alimentar, psicrotolerante.

\section{INTRODUCTION}

Presence of extracellular enzymes, mainly heat-stable lipases and proteases produced by Pseudomonas spp. during refrigeration of raw milk in dairy farms, causes spoilage of dairy products. These microorganisms can contaminate refrigerated raw milk and produce spoilage metabolites (spoilage activity) even at $4^{\circ} \mathrm{C}$ (Dogan \& Boor 2003, Arcuri et al. 2008).

Several bacteria genera have been described as psychrotolerant microorganisms and Pseudomonas is the genus of most technological relevance (Hantsis-Zacharov \& Halpern 2007). Since psychrotolerant microorganisms are commonly found in natural environment, dairy products can be contaminated by contact with water, inner surface of bulk tanks during storage of refrigerated raw milk, surface of cows' teats and equipment used throughout the milking process (Leriche et al. 2004, Fagundes et al. 2006, Teh et al. 2011). Therefore, the adoption of hygienic measures during milking process is necessary in order to reduce contamination with psychrotolerant microorganisms (Elmoslemany et al. 2010). So, the performance of molecular studies in order to evaluate the main contamination sources of raw milk with Pseudomonas spp. are required to understand which prophylactic measures are required to improve milk quality in Brazilian dairy farms.

Pseudomonas species have been isolated from different dairy products, such as cheeses, refrigerated raw milk, and pasteurized milk, while the presence of proteases has been described in ultra-high temperature (UHT) treated milk (Martins et al. 2006, Arslan et al. 2011, Beena et al. 2011, Chen et al. 2011). These enzymes are responsible for reducing dairy products shelf-life and destabilizing UHT milk (He et al. 2009, Baglinière et al. 2012). Pseudomonas spp. isolates also have high genetic diversity, different spoilage potential and antimicrobial resistance (Dogan \& Boor 2003, Martins et al. 2006, Marchand et al. 2009a,b, Marques et al. 2012). Therefore, the use of molecular techniques helps to describe the diversity of these milk contaminants (Ercolini et al. 2009).

So the aim of this study was to isolate Pseudomonas spp. throughout milking process in dairy farms with manual and mechanical milking systems, during rainy and dry seasons, as well as evaluating DNA homology between isolates in order to verify the most important sources of contamination of milk by these microorganism and their patterns of distribution.

\section{MATERIALS AND METHODS}

Farms characterization. This study was performed in ten dairy farms located at Pirassununga, state of São Paulo, Brazil, belonging to the Rural Regional of the Development Office (EDR) Limeira/SP, during dry and rainy seasons of 2014 and 2015. During the study period, the average rainfall in the rainy and dry seasons was 85.20 and $21.85 \mathrm{~mm}$, respectively (USP 2015). Cattle population size in these farms was from 10 up to 40 cross-breed cows on lactation and milk production ranging from 300 to 1.000 liters/daily. Milking was performed manually in five farms (A, C, $D, I, J)$, while milking was mechanical in the other five properties (B, E, F, G, H). All farms had expansion tanks. Pre-dipping was performed using commercial products containing $2 \%$ of chlorine solutions.

Sampling sites. A pool of swabs, water and milk were sampled from ten different sites during milking process (Table 1).

Pseudomonas spp. isolation. Pools of swabs were placed inside tubes containing $5 \mathrm{~mL}$ of $0.1 \%$ peptone water. A set of $500 \mathrm{~mL}$ of water and milk samples were collected in sterile glass flasks. Samples were kept in a cool box with recyclable ice until the analysis moment. Pseudomonas spp. enumeration was performed according to Cousin \& Bramley (1981). For this purpose, dilutions of the samples were prepared by transferring aseptically $25 \mathrm{~mL}$ of the sample to an Erlenmeyer containing $225 \mathrm{~mL}$ of $0.1 \%$ sterile peptone water $\left(10^{-1}\right.$ dilution). Tenfold dilution until a $10^{-5}$ dilution were prepared from the same diluents. Subsequently, $0.1 \mathrm{~mL}$ of the sample was spread with a Drigalski handle on plates containing supplemented (CFC-SR103-Oxoid) Pseudomonas Agar Base (CM 559, Oxoid). Plates were incubated at $28^{\circ} \mathrm{C}$ for 48 hours and colonies were counted with a colony counter and multiplied by the dilution factor. Isolates were stored in BHI broth with glycerol $50 \%$ and kept frozen at $-80^{\circ} \mathrm{C}$ until the DNA extraction procedure. Pseudomonas spp. isolates used in this study are the same ones from Capodifoglio et al. (2016), which focused on evaluating differences on Pseudomonas spp. counts and the spoilage potential from isolates during dry and rainy seasons. So, the samples sites were considered just as positive (1) or negative (0) for Pseudomonas spp. presence in this paper.

Statistical analyses. All sample points evaluated during dry and rainy seasons in the same farm were considered as pair wise. Also, the following sampling points (milker's hands before and after milking; teats' surface before and after pre-dipping; and teat cups before and after milking) were considered as pair wise. The evaluation among Pseudomonas spp. isolation in sampling sites during dry and rainy seasons and among farms with manual or

Table 1. Different sampling points in ten dairy farms with manual and mechanical milking systems located in Pirassununga municipality, São Paulo State, Brazil, during the dry and rainy seasons of 2014-2015

\begin{tabular}{cl}
\hline Number & \multicolumn{1}{c}{ Sample point } \\
\hline 1 & Sample of cow's drinking water \\
2 & Swab of milkers' hands before milking \\
3 & Swab of milkers' hands after milking \\
4 & Swab of the surface of cows' teats before pre-dipping \\
5 & Swab of the surface of cows' teats after pre-dipping \\
6 & Swab of internal surface of teat cups (mechanical milking) \\
7 & or milk bucket (manual milking) before milking \\
& Swab of internal surface of teat cups (mechanical milking) \\
8 & or milk bucket (manual milking) after milking \\
9 & Swab of internal surface of cooling tanks before milking \\
10 & Milk from cooling tanks immediately after milking \\
& Milk stored for 48 hours in the cooling tanks
\end{tabular}


mechanical milking was performed using binominal, chi-square or McNemar tests $(\mathrm{p}=0.05)$.

DNA extraction and quantification. DNA extraction was performed using DNAzol ${ }^{\circledR}$ (Invitrogen ${ }^{\mathrm{TM}}$ ) according to the manufacturer's instructions. A colony-forming unit for each sample site was collected and submitted to DNA extraction. Samples were subjected to DNA quantification by light absorbance using Nanodrop ${ }^{\circledR}$ spectrophotometry. All samples were stored at $-80^{\circ} \mathrm{C}$ until enzymatic digestion. The quantification of the isolated DNA ranged from 9.6 to $211.4 \mathrm{ng} / \mu \mathrm{l}$.

Digestion by restriction endonucleases. This research was based on AFLP Analysis System for Microorganisms (Life Technologies, Cat Numb. 11352-010 and 11352-018). The extracted genomic DNA was subjected to enzymatic digestion with two endonucleases (EcoR I and Mse I) simultaneously. EcoR I recognizes six pairs of nitrogenous bases (bp) (5'-GAATTC-3'), while Mse I recognizes a site of $4 \mathrm{bp}\left(5^{\prime}\right.$-TTAA-3').Each sample was adjusted to $60 \mathrm{ng} / \mu \mathrm{L}$ and incubated at $37^{\circ} \mathrm{C}$ for two hours with endonucleases solution (EcoRI / Mse I $1.25 \mathrm{U} / \mu \mathrm{L}+$ buffer solution + ultrapure water). Enzymes were denatured at $70^{\circ} \mathrm{C}$ for fifteen minutes.

Adapters' ligation. The digested DNA was subjected to ligation by EcoR I and Mse I adapters in order to generate the target DNA for amplification. Each sample received adapters' solution (adapters + T4 DNA ligase $1 \mathrm{U} / \mu \mathrm{L}$ ) and was incubated at room temperature $\left(18\right.$ to $\left.22^{\circ} \mathrm{C}\right)$ for two hours. Afterwards, samples were diluted (1:10) in Tris-EDTA (TE) solution and stored at $-20^{\circ} \mathrm{C}$ until amplification.

Pre-amplification reaction. Pre-amplification reaction was performed with primers E-0 (5'-GACTGCGTACCAATTC-3') and M-0 (5'-GATGAGTCCTGAGTAA-3'), in order to allow a selective amplification, resulting in cleaner fingerprints.

Selective amplification reaction for Pseudomonas spp. The selective amplification reaction was performed with two different pairs of recommended primers for Pseudomonas spp. analysis: E-C (5'-GACTGCGTACCAATTCC-3') and M-A (5'- GATGAGTCCTGAGTAAA-3'); and E-C and M-G (5'- GATGAGTCCTGAGTAAG-3'). The thermal cycling protocol used was based on touchdown PCR in order to increase specificity, sensitivity and yield. PCR is started at a very high annealing temperature to obtain optimal primer selectivity. In the following steps the annealing temperature is lowered gradually to a temperature are which efficient primer binding occurs. This temperature is then maintained for the rest of the
PCR cycles (Korbie \& Mattick, 2008).The annealing temperature began at $65^{\circ} \mathrm{C}$ per one cycle followed for 12 cycles with a decrease of $0.7^{\circ} \mathrm{C}$ per cycle (touchdown phase of 13 cycles). Then, 23 cycles at $56^{\circ} \mathrm{C}$ were performed. This reaction was performed in a final volume of $20 \mu \mathrm{L}$, according to manufacturer's instructions.

Polyacrylamide Gel Electrophoresis. The products from selective amplification reaction were separated using electrophoretic migration in denaturating polyacrylamide gel at $6 \%\left(\right.$ Novex $^{\circledR}$ TBE-Urea Gels, 6\%, 15 well, Invitrogen ${ }^{\mathrm{TM}}$ ). The samples were denatured at $70^{\circ} \mathrm{C}$ for three minutes using Novex ${ }^{\circledR} \mathrm{TBE}-U$ rea Sample Buffer (Invitrogen ${ }^{\mathrm{TM}}$ ). The standard molecular size 30 to $330 \mathrm{bp}$ AFLP $^{\circledR}$ DNA Ladder (Invitrogen ${ }^{\mathrm{TM}}$ ) was used. Electrophoresis was performed in X Cell Sure Lock ${ }^{\circledR}$ Mini-Cell (Invitrogen ${ }^{\mathrm{TM}}$ ) with Tris-Borato-EDTA (TBE) buffer using voltage between 150 and $200 \mathrm{~V}$ for about one hour.

Silver staining. The gel staining was performed using SilverXpress $^{\circledR}$ Silver Staining Kit (Invitroge ${ }^{\mathrm{TM}}$ ) according to manufacturer's instructions. It was possible to detect signal from $0.5 \mathrm{ng}$ of DNA fragments equal or larger than $50 \mathrm{bp}$.

AFLP electrophoretic migration pattern analysis. Images were analyzed using the software BioNumerics version 7.50 (AppliedMaths) after photographic documentation, and the images normalization was performed from the molecular size standard. The levels of similarity between the AFLP patterns were calculated using Dice's coefficient. A tolerance of $1 \%$ was accepted for correspondence among bands. The strains were grouped by UPGMA (Unweighted Pair Group Method of Arithmetic Means hierarchical method) for dendrograms construction (Geornaras et al. 1999). The isolates were considered as correlated when the similarity among them was higher than $80 \%$.

\section{RESULTS AND DISCUSSION}

A total of 167 isolates of Pseudomonas spp. were obtained from 200 samples in 10 dairy farms with manual and mechanical milking systems, during the dry and rainy seasons, as shown in Table 2.

Pseudomonas spp. were isolated from $100 \%$ of the cooling tank samples, $95 \%$ of samples collected from teat cups after milking and from empty bulk tanks, $90 \%$ of the samples from the surface of cows' teats before pre-dipping and milk samples stored for 48 hours, $85 \%$ of samples of

Table 2. Pseudomonas spp. isolated from different sampling points in ten dairy farms with manual and mechanical milking systems located in Pirassununga municipality, São Paulo State, Brazil, during the dry and rainy seasons of 2014-2015

\begin{tabular}{|c|c|c|c|c|c|c|c|c|c|c|c|c|c|c|c|c|c|c|c|c|c|c|}
\hline & \multirow{3}{*}{ Sites } & \multicolumn{20}{|c|}{ Farms } & \multirow{3}{*}{$\begin{array}{c}\text { Number } \\
\text { of } \\
\text { isolates }\end{array}$} \\
\hline & & \multicolumn{10}{|c|}{ Manual milking } & \multicolumn{10}{|c|}{ Mechanical milking } & \\
\hline & & $\mathrm{D}^{*}$ & $\mathrm{~W}^{* *}$ & $\mathrm{D}$ & $\mathrm{W}$ & $\mathrm{D}$ & W & $\mathrm{D}$ & W & $\mathrm{D}$ & $\mathrm{W}$ & $\mathrm{D}$ & W & $\mathrm{D}$ & W & $\mathrm{D}$ & $\mathrm{W}$ & $\mathrm{D}$ & $\mathrm{W}$ & $\mathrm{D}$ & W & \\
\hline 1 & Water & 1 & 1 & 1 & 1 & 1 & 1 & 1 & 1 & 1 & 0 & 1 & 0 & 1 & 0 & 1 & 0 & 1 & 1 & 0 & 0 & 14 \\
\hline 2 & Milkers' hands before milking & 1 & 1 & 1 & 1 & 1 & 1 & 0 & 1 & 1 & 1 & 0 & 1 & 1 & 1 & 1 & 1 & 0 & 1 & 0 & 1 & 16 \\
\hline 3 & Milkers' hands after milking & 1 & 1 & 1 & 1 & 1 & 1 & 0 & 1 & 1 & 1 & 0 & 1 & 1 & 1 & 1 & 1 & 0 & 1 & 1 & 0 & 16 \\
\hline 4 & Surface of cows' teats before pre-dipping & 1 & 1 & 1 & 1 & 1 & 1 & 1 & 1 & 1 & 1 & 0 & 1 & 1 & 1 & 1 & 1 & 1 & 1 & 0 & 1 & 18 \\
\hline 6 & Teat cups before milking & 0 & 1 & 1 & 1 & 1 & 1 & 0 & 1 & 1 & 1 & 0 & 1 & 1 & 1 & 1 & 1 & 1 & 1 & 1 & 1 & 17 \\
\hline 7 & Teat cups after milking & 1 & 1 & 1 & 1 & 1 & 1 & 0 & 1 & 1 & 1 & 1 & 1 & 1 & 1 & 1 & 1 & 1 & 1 & 1 & 1 & 19 \\
\hline 8 & Cooling tanks before milking & 1 & 1 & 1 & 1 & 1 & 1 & 0 & 1 & 1 & 1 & 1 & 1 & 1 & 1 & 1 & 1 & 1 & 1 & 1 & 1 & 19 \\
\hline 9 & $\begin{array}{l}\text { Milk from cooling tanks immediately } \\
\text { after milking }\end{array}$ & 1 & 1 & 1 & 1 & 1 & 1 & 1 & 1 & 1 & 1 & 1 & 1 & 1 & 1 & 1 & 1 & 1 & 1 & 1 & 1 & 20 \\
\hline 10 & $\begin{array}{l}\text { Milk stored for } 48 \text { hours in the } \\
\text { cooling tanks }\end{array}$ & 1 & 1 & 1 & 1 & 1 & 1 & 0 & 1 & 1 & 1 & 1 & 1 & 1 & 1 & 1 & 1 & 1 & 1 & 0 & 1 & 18 \\
\hline
\end{tabular}


the teat cups before milking, $80 \%$ of the samples collected from the milkers' hands before and after milking, $70 \%$ of water samples and $50 \%$ of the samples taken from cows' teats after pre dipping. These results highlight Pseudomonas spp. widespread in dairy farms environment due high quantity of positive samples.

Also, these results demonstrate that good hygienic practices are necessary to control Pseudomonas spp. contamination during the milking process and cold storage of raw milk in dairy farms, to improve the quality of milk used in manufacturing dairy products (Leitner et al. 2008, Vallin et al. 2009), since this bacterium is commonly reported as one of the main contaminants found in raw milk (Ercolini et al. 2009).

A total of 85 samples collected in properties with manual milking system were found to be positive for Pseudomonas spp., 40 collected during the dry season and 45 during the rainy season. On farms with mechanical milking, Pseudomonas spp. were isolated from 82 samples, of which 39 were taken during the dry season and 43 in the rainy season. This demonstrates a higher isolation rate in dairy farms with manual milking and during the rainy season. However, no significant differences $(p>0.05)$ were observed on Pseudomonas spp. isolation among farms with mechanical or manual systems or among dry and rainy seasons. In our previous manuscript, a higher isolation rate of these bacteria was found in rainy season (Capodifoglio et al. 2016).

According to Marchand et al. (2009a), Pseudomonas spp. counts and lipolytic Pseudomonas spp. percentages in raw milk from Belgian dairy farms were higher during the winter months, which could be attributed to the different housing management practices. During winter, animals are kept in closed stalls, while in the summer months, cows are released on pastures. However, this difference was not observed in this research. In the present research the sampling sites were considered as positive or negative and it can explain the difference observed.

A significant difference $(\mathrm{p}=0.02)$ on Pseudomonas spp. isolation was observed among samples of the surface of cows' teats before and after pre-dipping using commercial products. This result highlights the importance on adopting pre-dipping before cow's milking in order to reduce Pseudomonas spp. contamination of dairy products and improve milk quality. Furthermore, no significant difference ( $>0.05)$ was observed among milkers' hands before and after cow's milking and also among internal surface of teat cups (mechanical milking) or milk bucket (manual milking) before and after milking, demonstrating that contamination occurs during any step of milking process.

DNA amplification using the E-C and M-A or E-C and $M-G$ primers were positive in 76 and 61 samples from farms with manual and mechanical milking system, respectively. Eleven different patterns were found and named using Romans numerals (I to XI). Only isolates that have shown correlation higher than $80 \%$ among samples are listed in Tables 3 and 4, and were used to establish the contamination sources of raw milk as shown in Figure 1.

Dairy products can be contaminated with a set of microorganisms by contact with water, inner surface of bulk tanks during storage of refrigerated raw milk and surface of cows' teats and equipment used throughout the milking process (Leriche et al. 2004, Fagundes et al. 2006, Teh et al. 2011), however, no correlation was observed among isolates obtained from water and raw milk in our study, highlighting that water is not one of the most important Pseudomonas species contamination sources for raw milk in the studied farms.

For samples collected during the rainy season in farm B, raw milk isolates of Pseudomonas spp. were similar to those found on the surface of cows' teats after pre-dipping (V) and on the cooling tank wall (II). During dry season, Pseudomonas spp. isolates found in milk samples were associated to the isolates from teats surface after pre-dipping and teat cups after milking (I). These patterns indicate that failures in pre-dipping and inadequately cleaned and disinfected equipment could lead to contamination to the stored milk and reduce its shelf-life. It is known that microorganism detected in cow's teats has similarities with populations detected on raw milk in bulk tanks (Doyle et al. 2016). Another two patterns were detected (III and IV). They show correlation between milkers' hands after mi-

Table 3. Pseudomonas spp. isolates with a minimum of $80 \%$ of correlation with milk samples collected from the cooling tanks immediately after and 48 hours after milking in 10 dairy farms located in Pirassununga municipality, state of São Paulo, Brazil, during the rainy season of 2014-2015

\begin{tabular}{|c|c|c|c|c|}
\hline \multirow{3}{*}{ Farm } & \multicolumn{4}{|c|}{ Rainy season } \\
\hline & \multicolumn{2}{|c|}{ Primer MA } & \multicolumn{2}{|c|}{ Primer MG } \\
\hline & $\begin{array}{l}\text { Milk from cooling tanks } \\
\text { immediately after milking }\end{array}$ & $\begin{array}{c}\text { Milk stored for } \\
48 \mathrm{~h} \text { in cooling tanks }\end{array}$ & $\begin{array}{l}\text { Milk from cooling tanks } \\
\text { immediately after milking }\end{array}$ & $\begin{array}{l}\text { Milk stored for } 48 \mathrm{~h} \text { in } \\
\text { cooling tanks }\end{array}$ \\
\hline Ama & Not clustered & Not clustered & Not clustered & $\mathrm{X}$ \\
\hline Bme & Not clustered & cooling tank before milking & Not clustered & Teats surface after pre-dipping \\
\hline $\mathrm{Cma}$ & Not clustered & Not clustered & Not clustered & Not clustered \\
\hline Dma & Not clustered & $\mathrm{X}$ & $\mathrm{X}$ & $\mathrm{X}$ \\
\hline Eme & Not clustered & $\mathrm{X}$ & Not clustered & Not clustered \\
\hline Fme & $\mathrm{X}$ & $\mathrm{X}$ & $\mathrm{X}$ & $\mathrm{X}$ \\
\hline Gme & Not clustered & Not clustered & Not clustered & $\mathrm{X}$ \\
\hline Hme & Not clustered & Not clustered & $\mathrm{X}$ & $\mathrm{X}$ \\
\hline Ima & $\mathrm{X}$ & $\mathrm{X}$ & $\mathrm{X}$ & $\mathrm{X}$ \\
\hline Jma & Not clustered & Not clustered & Not clustered & Not clustered \\
\hline
\end{tabular}

$\overline{\mathrm{ma}}=$ manual milking system, $\mathrm{me}=$ mechanical milking system, $\mathrm{X}=$ no amplification or isolation. 
Table 4. Pseudomonas spp. isolates with a minimum of $80 \%$ of correlation with milk samples collected from the cooling tanks immediately after and 48 hours after milking in 10 dairy farms located in Pirassununga municipality, state of São Paulo, Brazil, during the dry season of 2014-2015

\begin{tabular}{|c|c|c|c|c|}
\hline \multirow{3}{*}{ Farm } & \multicolumn{4}{|c|}{ Dry season } \\
\hline & \multicolumn{2}{|c|}{ Primer MA } & \multicolumn{2}{|c|}{ Primer MG } \\
\hline & $\begin{array}{l}\text { Milk from cooling tanks } \\
\text { immediately after milking }\end{array}$ & $\begin{array}{l}\text { Milk stored for } 48 \mathrm{~h} \\
\text { in cooling tanks }\end{array}$ & $\begin{array}{l}\text { Milk from cooling tanks } \\
\text { immediately after milking }\end{array}$ & $\begin{array}{l}\text { Milk stored for } 48 \mathrm{~h} \text { in } \\
\text { cooling tanks }\end{array}$ \\
\hline Ama & $\mathrm{X}$ & Not clustered & $\mathrm{X}$ & $\mathrm{X}$ \\
\hline Bme & Not clustered & Not clustered & $\begin{array}{l}\text { Teats surface after pre-dipping } \\
\text { and teat cups after milking }\end{array}$ & $\begin{array}{c}\text { Teats surface after pre-dipping, } \\
\text { and teat cups after milking }\end{array}$ \\
\hline \multirow[t]{2}{*}{ Cma } & Milkers' hands after milking, & Bucket inner surface & $\mathrm{N}$ & \\
\hline & teats surface before pre-dipping & before milking & Not clustered & Not clustered \\
\hline Dma & Not clustered & $\mathrm{X}$ & $\mathrm{X}$ & $\mathrm{X}$ \\
\hline Eme & Not clustered & $\mathrm{X}$ & $\mathrm{X}$ & Not clustered \\
\hline Fme & $\mathrm{X}$ & $\mathrm{X}$ & $\mathrm{X}$ & $\mathrm{X}$ \\
\hline Gme & Cooling tank before milking & Cooling tank before milking & $\mathrm{X}$ & $\mathrm{X}$ \\
\hline Hme & Not clustered & $\mathrm{X}$ & Not clustered & $\mathrm{X}$ \\
\hline Ima & $\mathrm{X}$ & $\mathrm{X}$ & Not clustered & $\mathrm{X}$ \\
\hline Jma & Not clustered & Not clustered & $\mathrm{X}$ & $\mathrm{X}$ \\
\hline
\end{tabular}

$\overline{\mathrm{ma}}=$ manual milking system, $\mathrm{me}=$ mechanical milking system $\mathrm{X}=$ no amplification or isolation.

lking, cows' teats before milking and inner surface of teat cups, but apparently this contamination didn't reach the stored milk. Yet, it is important to notice that isolates from milkers' hands after milking and inner surface of teat cups after milking have shown $100 \%$ identity.

In dairy farm $\mathrm{C}$, relationships between contaminated milk samples and isolates from milkers' hands after milking and surface of cows' teats before pre-dipping (VII and VIII), and inner surface of the bucket before milking (VI) were observed during dry season. This highlights the need for reinforcing hygienic practices during all stages of milking process to avoid Pseudomonas spp. contamination in raw milk (Fagundes et al. 2006).

When evaluating samples obtained from farm $G$, it was observed that surface of the cooling tank was the main source of contamination for milk produced during the dry season (IX). This finding is interesting because highlights the role of tanks surface to milk contamination, which commonly is attributed to the environment where cows are maintained during rearing (Doyle et al. 2016). Another interesting fact is that, during rainy season, isolates from surface of cows' teats before pre-dipping and teat cups before milking were $100 \%$ identical (X), but genetically distant of those were contaminating the stored raw milk. In this case, the correlation between cooling tank and stored milk was not taken in account, but, there was almost $80 \%$ of similarity, demonstrating association with the results from rainy season.

Farm J presented a pattern between milk from cooling tanks immediately after milking and milk stored for 48 hours during dry season (XI), but it was not possible to trace the origin of this contamination. Nevertheless, during rainy season, a correlation was almost established between stored milk and inner surface of cooling tank before milking, but it didn't reach $80 \%$ of similarity.

Tables 3 and 4 show that the milkers' hands and surface of cows' teats before pre-dipping are important sources of contamination in dairy farms with manual milking system, while in farms with mechanical milking, the surface of cows' teats after pre-dipping, teat cups and cooling tanks also contribute to with Pseudomonas spp. contamination. For milk samples collected directly from the cooling tanks (immediately after and 48 hours after milking), the incidence of contamination reached almost $100 \%$, regardless of the type of milking system. Also, it was demonstrated the possibility of occurrence of Pseudomonas spp. contamination from different sources, demonstrating the need of adoption of hygienic management practices to avoid the dissemination of this bacteria. Furthermore, the formation of biofilms in the cooling tanks (Teh et al. 2011) also can be related to milk contamination by these microorganisms. Bacteria detected on farms can survive up to the receivement of milk in dairy industries causing technological failures (Almeida et al. 2017), i.e, bitterness, particle formation, creaming, sediment formation and gelation (Stoeckel et al. 2016).

As shown by Silva et al. (2011), when studying psychrotolerant bacteria (including Pseudomonas spp.), milkers' hands are one of the main sources of milk contamination in properties with manual milking. In this study, the importance of water, milkers' hands, surface of cows' teats, teat cups and cooling tanks as sources of contamination of raw milk with Pseudomonas spp. was highlighted. Molecular characterization of milk contaminants and a thorough understanding of the ecological and epidemiological aspects of Pseudomonas spp. are critical to establishing the most effective preventive measures (Ercolini et al. 2009) and to improving the quality of dairy products, since these microorganisms produce heat-resistant proteases, which cause technological failures that affect the processing steps during dairy products manufacturing (Marchand et al. 2009 b). It is interesting to compare Pseudomonas spp. contamination sources in milk with other bacteria as Bacillus cereus, a important foodborne and spoilage microorganism in dairy production chain, which commonly is found on soil (Kumari \& Sarkar 2016). According to Christiansson et al. (1999), the milking equipment did not contribute to milk's contamination, however, we highlighted the importance of them in Pseudomonas spp. contamination. Total counts 


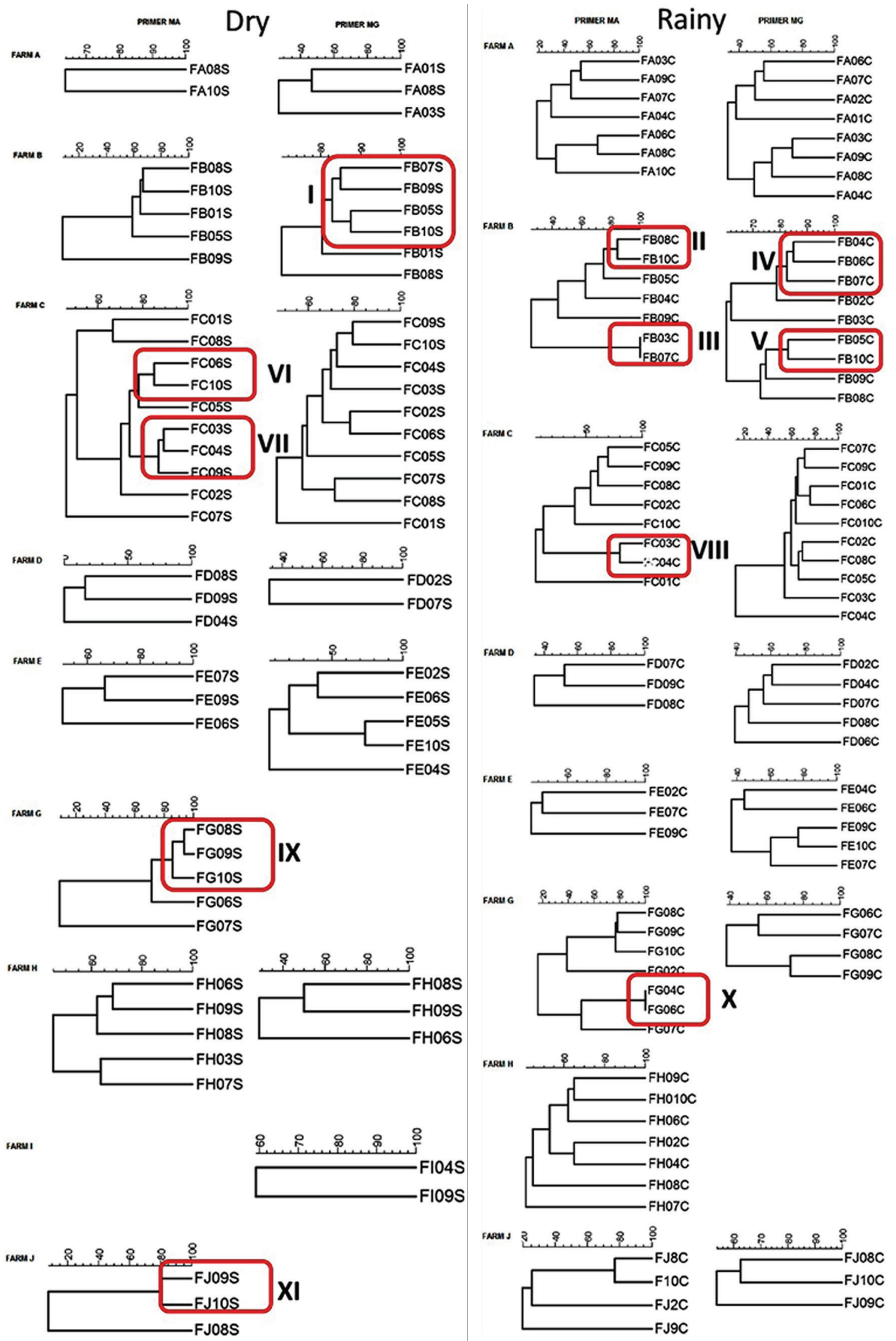

Fig.1. Dendrograms demonstrating genetic similarity between Pseudomonas spp. strains isolated at different sites in ten dairy farms during dry and rainy seasons of 2014-2015. (Subtitle: Farm (F), Farm letter (A, B, C, D, E, F, G, H, I, J), Site number (01, 02, 03, 04, 05, 06, 07, 08, 09 and 10), Dry season (S) or Rainy season (C). Romans numerals (I to XI) represent similarity patterns.) 
of Pseudomonas spp. can be reduced by adopting proper hygiene practices during the milking process and storage of refrigerated raw milk (Fagundes et al., 2006, Silva et al. 2011), emphasizing the need for improvements in the dairy farms evaluated in this study. Since Pseudomonas spp. can even affect the processing of ultra-high temperature treated dairy products (Chen et al. 2011, Baglinière et al. 2012), good hygienic measures can contribute to the quality of dairy products and industrial productivity of the dairy industry.

To reduce the count of Pseudomonas spp. in milk, milking equipment and utensils should be cleaned with water of good quality, and disinfected immediately after use (FAO \& WHO 1997). Pre-dipping should be properly performed (appropriate disinfectant solutions, concentration and period of action), once Pseudomonas spp. is able to survive in disinfectant solutions, such as those based on chlorhexidine and quaternary ammonium, (Nickerson 2001). In our study, pre-dipping was able on reducing Pseudomonas spp. detection on teats surface, stressing the need of adoption of this practice during milking, to improve the quality for raw milk and dairy products. Furthermore, the adoption of systems using continuos $\mathrm{N}_{2}$ gas-flushing of raw milk can reduce Pseudomonas spp. growth (Gschwendtner et al. 2016).

It has been demonstrated that periodic and effective cleaning of cooling tanks is crucial, since these are a major source of contamination by Pseudomonas spp. The presence of bacterial colonies in bulk tanks may not only represent an important a source of contamination by viable cells of Pseudomonas spp., but also the presence of heat stable enzymes produced by these microorganisms, that can be detrimental to the quality of milk and dairy products (Teh et al. 2011). Proper functioning of cooling tanks should also be of concern in order to rapidly cool the milk and prevent bacterial multiplication (Chye et al. 2004).

\section{CONCLUSIONS}

Pseudomonas spp. was isolated from all milk samples and from all sampling points, so the dissemination of Pseudomonas spp. in dairy farm environment was demonstrated.

Milkers' hands, surface of cows' teats, teat cups and cooling tanks were associated with raw milk contamination with Pseudomonas spp. on farms with manual and mechanical milking system, showing that regardless of the type of milking system and season, proper hygiene procedures of equipment, utensils and workers' hands are essential to avoid contamination of raw milk.

Acknowledgements.- The authors are grateful to São Paulo Research Foundation (FAPESP) for the financial support of this work (Process no. 2013/04131-2 and 2017/05587-0) and scholarship support by PIBIC-CNPq (Brazilian National Council for Scientific and Technological Development).

\section{REFERENCES}

Almeida K.M., Bruzaroski S.R., Zanol D., Melo M., Santos J.S., Alegro L.C.A., Botaro B.G. \& Santana E.H.W. 2017. Pseudomonas spp. and Pseudomonas fluorescens: population in refrigerated raw milk. Ciência Rural 47:e20151540.

Arcuri E.F., Silva P.D.L., Brito M.A.V.P., Brito J.R.F. Lange C.C. \& Magalhães
M.M.A. 2008. Counting, isolation and characterization of psychrotrophic bacteria from refrigerated raw milk. Ciência Rural 38:2250-2255.

Arslan S., Eyi A. \& Ozdemir F. 2011. Spoilage potentials and antimicrobial resistance of Pseudomonas spp. isolated from cheeses. J. Dairy Sci. 94:5851-5856.

Baglinière F., Tanguy G., Jardin J., Matéos A., Briard V., Rousseau F., Robert B., Beaucher E., Humbert G., Dary A., Gaillard J.L., Amiel C. \& Gaucheron F. 2012. Quantitative and qualitative variability of the caseinolytic potential of different strains of Pseudomonas fluorescens: Implications for the stability of casein micelles of UHT milks during their storage. Food Chem. 135:2593-2603.

Beena A.K., Ranjini A.R. \& Riya T.G. 2011. Isolation of psychrotrophic multiple drug resistant Pseudomonas from pasteurised milk. Vet. World 4:349-352.

Capodifoglio E., Vidal A.M.C., Lima J.A.S., Bortoletto F., D’Abreu L.F., Gonçalves A.C.S., Vaz A.C.N., Balieiro J.C. \& Saran-Netto A. 2016. Lipolytic and proteolytic activity of Pseudomonas spp. isolated during milking and storage of refrigerated raw milk. J. Dairy Sci. 99:5214-5223.

Chen T.R., Wei Q.K. \& Chen Y.J. 2011. Pseudomonas spp. and Hafnia alvei growth in UHT milk at cold storage. Food Control 22:697-701.

Christiansson A., Bertilsson J. \& Svensson B. 1999. Bacillus cereus spores in raw milk: factors affecting the contamination of milk during grazing period. J. Dairy Sci. 82:305-314.

Chye F.Y., Abdullah A. \& Ayob M.K. 2004. Bacteriological quality and safety of raw milk in Malaysia. Food Microbiol. 21:535-541.

Cousin M.A. \& Bramley A.J. 1981. The microbiology of raw milk. In: Robinson R.K. Dairy microbiology of milk. Applied Science Publishers, London, p.119-163.

Dogan B. \& Boor K.J. 2003. Genetic diversity and spoilage potentials among Pseudomonas spp. isolated from fluid milk products and dairy processing plants. Appl. Environ. Microbiol. 69:130-138.

Doyle C.J., Gleeson D., O'Toole P.W. \& Cotter P.D. 2016. Impacts of seasonal housing and teat preparation on raw milk microbiota: a high-throughput sequencing study. Appl. Environ. Microbiol 83:e02694-16.

Elmoslemany A.M., Keefe G.P., Dohoo I.R., Wichtel J.J., Strynh H. \& Dingwell R.T. 2010. The association between bulk tank milk analysis for raw milk quality and on-farm management practices. Prev. Vet. Med. 95:32-40.

Ercolini D., Russo F., Ferrocino I. \& Villani F. 2009. Molecular identification of mesophilic and psychrotrophic bacteria from raw cow's milk. Food Microbiol. 26:228-231.

Fagundes C.M., Fischer V., Silva W.P., Carbonera N. \& Araújo M.R. 2006. Presence of Pseudomonas spp in milking phases with different hygienic handling procedures and in refrigerated Milk. Ciência Rural 36:568-572.

FAO \& WHO 1997. General requirements (Food Hygiene). Codex Alimentarius, Vol.1B (Suppl.). Food and Agriculture Organization, Rome.

Geornaras I., Kunene N.F., von Holy A. \& Hastings J.W. 1999. Amplified Fragment Length Polymorphism Fingerprinting of Pseudomonas strains from a poultry processing plant. Appl. Environ. Microbiol. 65:3828-3833.

Gschwendtner S., Alatossava T., Kublik S., Fuka M.M., Schloter M. \& Munsch-Alatossava P. 2016. $\mathrm{N}_{2}$ gas flushing alleviates the loss of bacterial diversity and inhibits psychrotrophic Pseudomonas during the cold storage of bovine raw milk. PLoS One 11(1):e0146015.

Hantsis-Zacharov E. \& Halpern M. 2007. Culturable psychrotrophic bacterial communities in raw milk and their preoteolytic and lipolytic traits. Appl. Environ. Microbiol. 73:7162-7168.

He H., Dong J., Lee C.N. \& Li Y. 2009. Molecular analysis of spoilage-related bacteria in pasteurized milk during refrigeration by PCR and denaturing gradient gel electrophoresis. J. Food Prot. 72:572-577.

Korbie D.J. \& Mattick J.S. 2008. Touchdown PCR for increased specificity and sensitivity in PCR amplification. Nature Protocol 3:1452-1458.

Kumari S. \& Sarkar P. K. 2016. Bacillus cereus hazard and control in industrial dairy processing environment. Food Control 69:20-29.

Leitner G., Silanikove N., Jacobi S., Weisblet L., Bernstein S. \& Merin U. 2008. The influence of storage on the farm and in dairy silos on milk quality for cheese production. Int. Dairy J. 18:109-113. 
Leriche F., Bordessoules A., Fayolle K., Karoui R., Laval K., Leblanc L. \& Dufour E. 2004. Alteration of raw-milk cheese by Pseudomonas spp.: monitoring the sources of contamination using fluorescence spectroscopy and metabolic profiling. J. Microbiol. Methods 59:33-41.

Marchand S., Heylen K., Messens W., Coudijzer K., Vos P., Dewettinck K., Herman L., Block J. \& Heyndrickx M. 2009a. Seasonal influence on heat-resistant proteolytic capcity of Pseudomonas lundensis and Pseudomonas fagi, predominant milk spoilers isolated from Belgian raw milk samples. Environ. Microbiol. 11:467-482.

Marchand S., Vandriesche G., Coorevits A., Coudijzer K., Jonghe V., Dewettinck K., Vos P., Devreese B., Heyndrickx M. \& Block J. 2009b. Heterogeneity of heat-resistant proteases from milk Pseudomonas species. Int. J. Food Microbiol. 133:68-77.

Marques S.C., Evangelista S.R. \& Piccoli R.H. 2012. Diversity of psychotrophic bacteria isolated from the milk cooling collective tanks and antibiotics resistance profile of the microorganisms isolates. Revta Inst. Adolfo Lutz, São Paulo, 71:670-676.

Martins M.L., Pinto C.L.O., Rocha R.B., Araújo E.F. \& Vanetti M.C.D. 2006. Genetic diversity of Gram-negative, proteolytic, psychrotrophic bacteria isolated from refrigerated raw milk. Int. J. Food Microbiol. 111:144148.

Nickerson S.C. 2001. Choosing the best teat dip for mastitis control and milk quality.NMC-PDPW Milk Quality Conference Proceedings, April 2001, p.43. Available in <http://www.nmconline.org/articles/teatdip. htm $>$ Accessed on 13 Jan. 2016.

Silva L.C.C., Beloti V., Tamanini R., Ovidio L., Mattos M.R., Arruda A.M.C.T \& Pires E.M.F. 2011. Tracking sources of microbiologic contamination of raw milk during milking process in dairy farms from Agreste of Pernambuco. Semina, Ciênc. Agrárias 32:267-276.

Stoeckel M., Lidolt M., Achberger V., Gluck C., Krewinkel M., Stressler T., Neubeck M., Wenning M., Scherer S., Fischer L. \& Hinrichs J. 2016. Growth of Pseudomonas weihenstephanensis, Pseudomonas proteolytica and Pseudomonas sp. in raw milk: Impact of residual heat-stable enzyme activity on stability of UHT milk during shelf-life. Int. Dairy J. 59:20-28.

Teh K.H., Flint S., Palmer J., Lindsay D., Andrewes P. \& Bremer P. 2011. Thermo-resistant enzyme-producing bacteria isolated from the internal surfaces of raw milk tankers. Int. Dairy J. 21:742-747.

USP 2015. Weather Station, University of Sao Paulo, Campus Pirassununga. Accessed on Aug. 23, 2015. <ftp://ftp.cisc.usp.br/pub/ PCAPS/estacao.html>

Vallin V.M., Beloti V., Battaglini A.P., Tamanini R., Fagnani R., Angela H.L. \& Silva L.C.C. 2009. Milk quality improvement after implantation of good manufacturing practices in milking in 19 cities of the central region of Paraná. Semina, Ciênc. Agrárias 30:181-188. 